\title{
Searching for the seafloor signature of the 21 May 2003 Boumerdès earthquake offshore central Algeria
}

\author{
A. Cattaneo ${ }^{1}$, N. Babonneau ${ }^{2}$, G. Ratzov ${ }^{2}$, G. Dan-Unterseh ${ }^{2, *}$, K. Yelles $^{3}$, R. Bracène ${ }^{4}$, B. Mercier de Lépinay ${ }^{5}$, \\ A. Boudiaf ${ }^{6}$, and J. Déverchère ${ }^{2}$ \\ ${ }^{1}$ Ifremer, GM-LES, BP70, 29280 Plouzané, France \\ ${ }^{2}$ Université de Brest, IUEM-CNRS UMR6538, Domaines Océaniques, 29280 Plouzané, France \\ ${ }^{3}$ CRAAG, Route de l'Observatoire, BP 63, Algiers, Algeria \\ ${ }^{4}$ SONATRACH, Division Exploration, Boumerdès, Algeria \\ ${ }^{5}$ Géosciences Azur, CNRS-UMR6526, 250 rue A. Einstein, 06560 Valbonne, France \\ ${ }^{6}$ Consultant and enseignant vacataire, Université des Sciences Montpellier2, 42 rue du Moulin à vent, 34200 Sète, France \\ *now at: FUGRO FRANCE S.A.S., 27 Rue des Peupliers, 92752, Nanterre, France
}

Correspondence to: A. Cattaneo (antonio.cattaneo@ifremer.fr)

Received: 29 November 2011 - Revised: 12 April 2012 - Accepted: 19 April 2012 - Published: 10 July 2012

\begin{abstract}
Shaking by moderate to large earthquakes in the Mediterranean Sea has proved in the past to potentially trigger catastrophic sediment collapse and flow. On 21 May 2003, a magnitude 6.8 earthquake located near Boumerdès (central Algerian coast) triggered large turbidity currents responsible for 29 submarine cable breaks at the foot of the continental slope over $\sim 150 \mathrm{~km}$ from west to east. Seafloor bathymetry and backscatter imagery show the potential imprints of the 2003 event and of previous events. Large slope scarps resulting from active deformation may locally enhance sediment instabilities, although faults are not directly visible at the seafloor. Erosion is evident at the foot of the margin and along the paths of the numerous canyons and valleys. Cable breaks are located at the outlets of submarine valleys and in areas of turbiditic levee overspilling and demonstrate the multi-source and multi-path character of the 2003 turbiditic event. Rough estimates of turbidity flow velocity are not straightforward because of the multiple breaks along the same cable, but seem compatible with those measured in other submarine cable break studies elsewhere.

While the signature of the turbidity currents is mostly erosional on the continental slope, turbidite beds alternating with hemipelagites accumulate in the distal reaches of sediment dispersal systems. In perspective, more chronological work on distal turbidite successions offshore Algeria offers promising perspectives for paleoseismology reconstructions based on turbidite dating, if synchronous turbidites along
\end{abstract}

independent sedimentary dispersal systems are found to support triggering by major earthquakes. Preliminary results on sediment core PSM-KS23 off Boumerdès typically show a 800 -yr interval between turbidites during the Holocene, in accordance with the estimated mean seismic cycle on land, even if at this stage it is not yet possible to prove the earthquake origin of all the turbidites.

\section{Introduction}

Moderate to large magnitude earthquakes occurring in the vicinity of coastal zones are well known to trigger phenomena such as tsunamis and sediment gravity collapses on land and at sea and to produce important threats linked to high vulnerability (population density, concentration of industries). Although subduction zones are among the most frequently affected by these catastrophic events, as recently evidenced in Sumatra (e.g. Dean et al., 2010), Chile (Vigny et al., 2011) and Japan (Koketsu et al., 2011; Furumura et al., 2011), it is worth to address these threats in coastal areas that underwent scarce and uneven seismic activity, because they are even less prepared to face their devastating effects.

In the submarine realm, catastrophic events along siliciclastic margins include submarine failures, turbidity flows (generated by river flows, earthquakes and wave resuspension) and seafloor ruptures by active faults (e.g. Einsele,

Published by Copernicus Publications on behalf of the European Geosciences Union. 
1996; Wright and Friedrichs, 2006). The monitoring of submarine processes in real-time is a difficult task that is increasingly problematic when relatively rare and catastrophic events are to be illustrated. Furthermore, the search for seafloor signatures of such catastrophic events remains elusive, owing to the erosional nature of the event and to the concurrent action of several related processes (sediment failure, turbidity flow ignition).

In areas where strong earthquakes are relatively rare, like the western Mediterranean Sea and the Atlantic Ocean, the first documented evidence for a possible large impact off coastal zones after a large earthquake is testified by the Messina 1908 earthquake in the Strait of Sicily, Italy (Baratta, 1910; Ryan and Heezen, 1965), followed by the 1929 Grand Banks event offshore Newfoundland, Canada (Piper and Aksu, 1987; Piper et al., 1988, 1999). More recently, the Algerian coastal zone, an area representing the limit between the African and Eurasian plates, has also undergone several events of sufficient magnitude to trigger large gravity effects testified by submarine cable breaks in the deep basin in 1954 (Heezen and Ewing, 1955), 1980 (ElRobrini et al., 1985), and 2003 (Carter et al., 2009). In particular, the $2003 \mathrm{Mw} 6.8$ Boumerdès earthquake was one of the most devastating historical seismic events in the western Mediterranean and generated significant gravity flows recognized by numerous submarine cable breaks at the foot of the margin and in the deep Algerian basin, leading to a nearly complete stop of all telecommunication exchanges in Algeria for about $48 \mathrm{~h}$. However, most of the studies on the impacts of the 2003 Boumerdès event were carried out on land (Ayadi et al., 2003; Bounif et al., 2004; Delouis et al., 2004; Meghraoui et al., 2004; Semmane et al., 2005), whereas little attention has been paid until now to its effects and signatures offshore.

The aim of this paper is to provide a full overview of the offshore impact of the 2003 Boumerdès earthquake, using detailed swath bathymetry, backscattering imagery, highresolution side-scan sonar data gathered in the area during the MARADJA 2003 and MARADJA2-SAMRA 2005 cruises (Déverchère et al., 2005; Domzig et al., 2006; DanUnterseh et al., 2011) and the PRISME 2007 cruise (Dan et al., 2009; Cattaneo et al., 2010; Nouguès et al., 2010). The fragmented tectonic setting of the Algerian margin is an impellent reason to study the record of past earthquakes in great detail in order to evaluate the size of faults and the related earthquake magnitudes. The 2003 event is a particularly interesting case owing to the exceptional impact at the seafloor through cable ruptures (Van Oudheusden, 2003). This fact, together with the need to assess geological hazards for coastal populations along the densely populated western Mediterranean coastline, justifies undergoing a detailed study in the hope to obtain information about the seafloor signatures of a catastrophic event, its likelihood of being preserved, and in general the relationships between seismicity and triggering of turbidity currents, seafloor failures and tsunamis. For this reason we also present the potential of distal turbiditic deposition in the area offshore Algiers as a promising tool to reconstruct the paleosismological history of the area.

\section{Background: the Boumerdès earthquake}

\subsection{Tectonic setting and seismicity}

The Algerian margin is a Cenozoic passive margin located close to the diffuse plate boundary between Eurasia and Africa, presently reactivated in compression (Stich et al., 2006, and references therein). Both offshore and on land, the deformation is expressed by distributed ESE-WNW-trending scarps that are assumed to represent the activity of thrustfold systems (e.g. Avouac et al., 1992; Déverchère et al., 2005; Domzig et al., 2006; Kherroubi et al., 2009; Yelles et al., 2006, 2009). These structures are associated with crustal shortening (Calais et al., 2003; Serpelloni et al., 2007) and moderate to large magnitude earthquakes (Ambraseys and Vogt, 1988; Yelles et al., 2006).

The morphology of the continental slope off central Algeria presents abrupt scarps that at least partly correspond to active tectonic structures, often identified at depth by Plio-Quaternary growth strata developing above ramps (Déverchère et al., 2005; Domzig et al., 2006; Kherroubi et al., 2009; Strzerzynski et al., 2010). Numerous submarine landslides are found along these structures at the surface and in the subsurface (e.g. Dan et al., 2010; Cattaneo et al., 2010), possibly indicating a link between seismicity and seafloor instability.

The Algerian continental margin is one of the most seismically active areas in the western Mediterranean, having experienced several moderate to strong earthquakes during the last centuries in the coastal zone (Benouar, 1993; Hamdache et al., 2010). The catalogue 856-2008 AD reveals that about 22 earthquakes of magnitude 6 and more have shaken the coastal strip of Algeria (over $\sim 100 \mathrm{~km}$ wide). Among these events, one third occurred certainly offshore, and the same amount exceeded magnitude 7. In the XIXth century, the two shocks that destroyed the region of Jijel on 21 and $22 \mathrm{Au}-$ gust 1856 were among the most significant that have affected north Africa (Harbi et al., 2011, and references therein); this sequence triggered a significant tsunami and reached an earthquake magnitude of at least 6.6, probably about 7 or more (Harbi et al., 2011; Yelles-Chaouche et al., 2009). The most violent instrumentally recorded earthquake occurred on 10 October 1980 in El Asnam region (Chlef currently) and reached a magnitude Ms of 7.3 (Ambraseys, 1981). More recently, on 21 May 2003, an earthquake with a magnitude of 6.8 struck the city of Boumerdès, east of Algiers on the coast. 


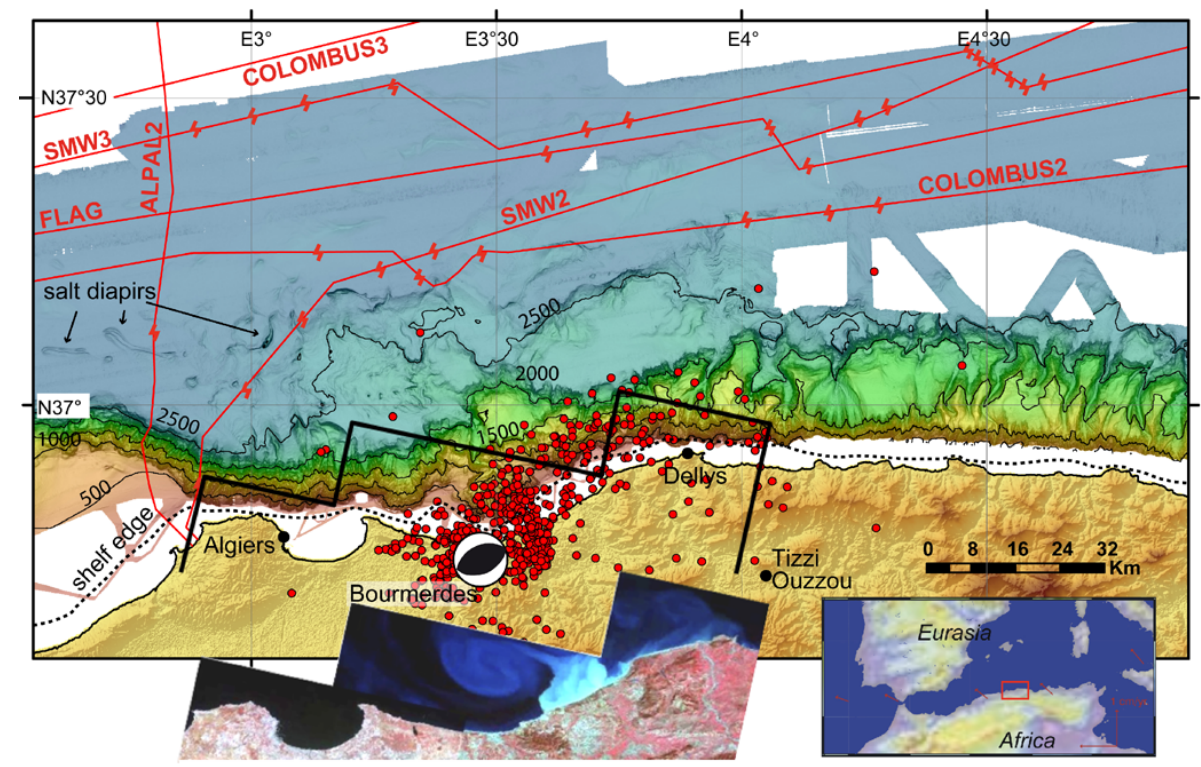

Fig. 1. Bathymetric map of the central Algerian margin with the layout of six offshore telecommunication cables and the location of cable breaks that occurred after the 2003 Boumerdès earthquake (red symbols). The epicenter of the M 6.82003 Boumerdès earthquake is represented by its focal mechanism, while red circles represent the location of the associated aftershocks. The interval of bathymetric contour is $500 \mathrm{~m}$. The location of the shelf edge is derived from navigation maps as reported in Cattaneo et al. (2010). The inset shows a Landsat image of the sediment plume off Boumerdès that originated after the earthquake.

\subsection{The 2003 Boumerdès earthquake and linked phenomena}

The 2003 Boumerdès earthquake caused more than 2300 deaths and injured around 10000 people. Besides casualties, the earthquake produced important damage onshore (collapse of many buildings; see e.g. Harbi et al., 2007) and offshore (cable breaks, e.g. ICPC, 2009). The identification of active fault segments and earthquake sources has received special attention by the scientific community, since this was the first well-documented event at the coastline in north Africa, furthermore located close to the highly populated city of Algiers.

The first important concern is related to the size and position of the earthquake rupture: although the models differ slightly (e.g. Bounif et al., 2004; Delouis et al., 2004; Meghraoui et al., 2004; Yelles et al., 2004; Semmane et al., 2005), there is general agreement to estimate the length of the rupture zone at about $60 \mathrm{~km}$ in a ca. $\mathrm{N} 65^{\circ} \mathrm{E}$ strike, and the rupture depth of the fault plane between 5 and $13 \mathrm{~km}$. Because of the lack of direct evidence, the trajectory of the rupture towards the surface is more controversial. Ayadi et al. (2008) propose that the rupture reached the surface at approximately the shelf edge, i.e. very close to the coastline, whereas Déverchère et al. $(2005,2010)$ and Mahsas et al. (2008) favour a flat-ramp geometry of the fault system, leading them to postulate a cumulative fault scarp at ca. $5-10 \mathrm{~km}$ from the coastline. The available focal mecha- nisms indicate an almost pure reverse faulting and a NNWSSE-directed regional maximum shortening axis (Stich et al., 2006; Ayadi et al., 2008). The thrusting was responsible for a mean coastal uplift of about $0.5 \mathrm{~m}$, reaching locally almost $0.8 \mathrm{~m}$ (Meghraoui et al., 2004), as well as for significant coand post-seismic (over $2.5 \mathrm{yr}$ ) displacements (Yelles et al., 2004; Mahsas et al., 2008).

Whatever the case, we consider for the sake of this study that severe ground shaking affected the area and was indeed able to trigger numerous relatively small-size submarine landslides on the continental slope offshore. Previous studies in the area (e.g. Dan et al., 2010; Cattaneo et al., 2010; Dan-Unterseh et al., 2011) have shown that the slope is prone to various types of instabilities that are mainly located on canyon flanks or heads, at the foot of the continental slope, and along scarps of tectonic origin.

A satellite image by NASA shot in the hours following the earthquake shows the presence of a sediment plume centered around Boumerdès (Fig. 1). A sea retreat was observed along parts of the Algerian coastline, while a tsunami was recorded in several harbours across the western Mediterranean Sea, especially at the Balearic Islands (Alasset et al., 2006) and in the Nice area (Sahal et al., 2009). A recent study (Roger et al., 2011) shows that the $1980 \mathrm{El}$ Asnam event, located far inside the continent, also triggered a tsunami that is assumed to have resulted directly from the coseismic displacements, and not from triggered mass movements of sediments. Several cable breaks occurred after the 2003 Boumerdès earthquake 
Table 1. Time of rupture of five submarine cables offshore the central Algerian margin (France Telecom, personal communication, 2003) after the earthquake (QK) of Boumerdès, 21 May 2003.

\begin{tabular}{llrrrr}
\hline Event & $\begin{array}{l}\text { Cable } \\
\text { name }\end{array}$ & $\begin{array}{r}\text { N. of } \\
\text { breaks }\end{array}$ & $\begin{array}{r}\text { time } \\
\text { (UTC) }\end{array}$ & $\begin{array}{r}t \text { post QK } \\
(\text { hh:mm })\end{array}$ & $\begin{array}{r}t \text { post QK } \\
(\mathrm{min})\end{array}$ \\
\hline earthquake & - & - & $18: 44: 00$ & $00: 00$ & 0 \\
cable break & SMW 2 & 7 & $19: 20: 00$ & $00: 36$ & 36 \\
cable break & COLOMBUS 2 & 6 & $19: 30: 00$ & $00: 46$ & 46 \\
cable break & FLAG & 3 & $20: 40: 00$ & $01: 56$ & 116 \\
cable break & SMW 3 & 11 & $21: 33: 00$ & $02: 49$ & 169 \\
cable break & ALPAL 2 & 1 & $22: 32: 00$ & $03: 48$ & 228 \\
\hline
\end{tabular}

(Table 1). However, the pattern of cable breaks is far from straightforward, because several ruptures occurred along the same cable, crossing several canyon valleys over remarkable distances.

\section{Data and methods}

This study focuses on a set of seafloor features possibly due to sediment instability, erosion, transport and accumulation that are particularly evident from bathymetry, backscatter imagery and side-scan sonar images complemented by sediment sampling. The study area encompasses a sector of the Algerian margin comprised between $2^{\circ} 40^{\prime}$ and $4^{\circ} 40^{\prime}$ longitude East, from the continental slope to the abyssal plain, where several submarine cables broke following the 2003 Boumerdès earthquake. The dataset includes results from three campaigns led from 2003 to 2007 in the offshore area of Boumerdès: MARADJA and MARADJA2/SAMRA (2003 and 2005, R/V Le Surôit), and PRISME (2007, R/V L'Atalante).

Swath bathymetry and backscatter data were collected with a Simrad EM300 multibeam echosounder and processed using the Caraibes software (Ifremer, France). This allowed to obtain a digital terrain model, a gradient map and a seafloor reflectivity map with a spatial resolution of $50 \mathrm{~m}$ (Figs. 1 and 2). The general bathymetric map allowed a detailed study of seafloor morphology and the identification of submarine canyons. Moreover, a deep-towed side-scan sonar (SAR, Sonar Acoustique Remorqué), towed about 80-100 m above the seafloor with a signal frequency of $180 \mathrm{kHz}$ and a 1000-m wide swath, allowed a detailed investigation of the seafloor texture and micro-morphology with a spatial resolution of $25 \mathrm{~cm}$, with dark tones representing high backscatter values.

Among the sediment cores collected in the study area, we present a 11.95-m long Kullenberg piston core collected in $2775 \mathrm{~m}$ water depth to provide a distal record of turbidite deposits interbedded in hemipelagites. Available data for the core include a lithologic description, high resolution photo, X-ray images obtained with SCOPIX (Migeon et al., 1999), Geotek Multi-Sensor Core Logging data (gamma density, Pwave velocity and magnetic susceptibility), elemental semi- quantitative logs obtained with an Avaatech XRF core logger (Richter et al., 2006) and four AMS radiocarbon dates (Table 2).

\section{Results}

\subsection{Morphology overview}

The Algerian continental shelf is relatively narrow, 5 to $10 \mathrm{~km}$ wide on average. It is virtually absent $(<2 \mathrm{~km})$ in some areas offshore Dellys, where the mountain ranges are close to the coastline, while it reaches up to $40 \mathrm{~km}$ in width offshore the main embayments (Domzig et al., 2006; Cattaneo et al., 2010). The continental shelf break lies between 100 and $200 \mathrm{~m}$ water depth and is indented where submarine canyon heads cut into the shelf. The continental slope is generally steep (often $>10^{\circ}$, locally up to $20^{\circ}$ ), cut by numerous canyons of various widths and heights, and includes some perched slope basins (Déverchère et al., 2005). It extends from $100-200$ to $2300-2500 \mathrm{~m}$, with a very variable width commonly between 8 and $20 \mathrm{~km}$. The main sediment transport systems (including submarine canyons, submarine valleys with channel complexes) are outlined in Fig. 2. The abyssal plain is characterized by elongated sinuous features interpreted as salt walls and diapirs (Dan-Unterseh et al., 2011, their Fig. 2; Figs. 1-2). These structures define multiple small basins (Fig. 1) typical of salt spreading (Gaullier and Vendeville, 2005). In order to seek the offshore signature of the 2003 earthquake and the associated rupture of submarine cables, we consider a set of seafloor features: (1) traces of seafloor rupture and instability, including submarine landslides, and (2) traces of sediment erosion/accumulation resulting from turbidity currents flowing through the main sedimentary systems and possibly generated by the 2003 and/or previous earthquakes.

\subsection{Seafloor scarps and submarine landslides}

Faults outcropping at the seafloor and earthquake-triggered landslide scars represent the possible direct signature of an earthquake in the subaqueous domain. Offshore Algeria, the presence and position of faults visible at or near the shallow subsurface are debated in the case of the Boumerdès 2003 earthquake (see, for example, Ayadi et al., 2008; Déverchère et al., 2010). A remarkable observation is the presence of several elongated seafloor scarps of likely tectonic origin, first described by Déverchère et al. (2005). In the distal, deeper part of the study area, the scarps S1, S2 and S3 (Fig. 2) are strikingly visible both in the bathymetry (Fig. 1) and in backscatter imagery (Fig. 2), especially in the Dellys area, where they extend $\mathrm{W}-\mathrm{E}$ for $30-40 \mathrm{~km}$. These scarps define the limits of perched basins on the slope and have the steepest flank seawards, likely representing the seafloor expression of blind thrust faults (Strzerzynski et al., 2010; Dan-Unterseh et al., 2011). 

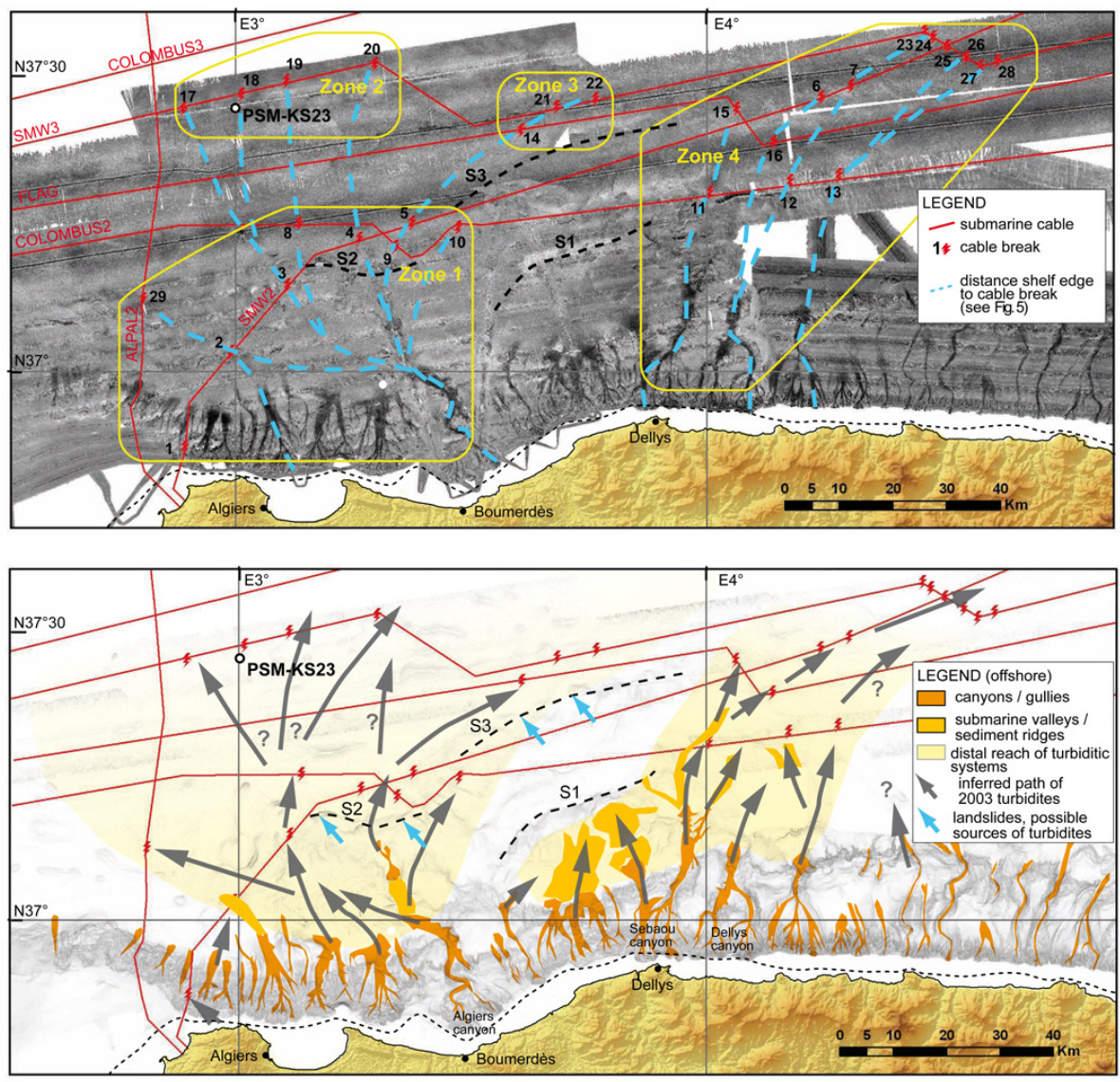

Fig. 2. Above: backscatter map of the central Algerian margin with the location of submarine cable breaks and of sediment core PSM-KS23 in the distal reaches of the Algiers turbiditic system close to one of the submarine cable breaks. Dark tones identify high backscatter areas, in particular along the thalwegs of the main canyon and turbiditic systems. In blue are the possible trajectories of turbidity flows inferred from the seafloor morphology. Below: interpretation of bathymetry and backscatter in terms of morphology and sedimentary processes in the area affected by the 2003 event. In dark orange are zones of dominant erosion within the axial areas of the main canyons; in light orange are zones of significant deposition; in yellow are the main sedimentary systems. The distal seafloor scarp S1 (black dashed lines, described in Déverchère et al., 2005 together with the other scarps S2 and S3) defines a structural high and limits seaward a perched basin, likely an expression of buried thrust-folds. Grey arrows represent the possible path of the 2003 turbidity currents interpreted from cable breaks, bathymetry, and backscatter. Blue arrows identify possible distal sources of submarine landslides and/or turbidites. Note the absence of cable breaks in the central part of cables COLOMBUS2 and SMW2, possibly due to deflection of turbidity currents by the scarps and confinement within a perched basin.

Table 2. Radiocarbon age of four hemipelagic beds of core PSM-KS23 obtained by AMS dating performed at Poznan Radiocarbon Laboratory, Poland (Poz) and at Artemis facility, Saclay, France (SacA). The ${ }^{14} \mathrm{C}$ ages were corrected for a reservoir effect of $400 \mathrm{yr}$, calibrated with Calib 6.0 (Stuiver et al., 2010) and reported as 2 sigma values.

\begin{tabular}{lllllll}
\hline $\begin{array}{l}\text { Sample } \\
\text { depth }(\mathrm{cm})\end{array}$ & Dated material & $\begin{array}{l}\text { wgt } \\
(\mathrm{mg})\end{array}$ & Lab code & $\begin{array}{l}{ }^{14} \mathrm{C} \text { age } \\
(\mathrm{yr})\end{array}$ & $\begin{array}{l} \pm \\
(\mathrm{yr})\end{array}$ & $\begin{array}{l}\text { Cal age } \\
(\mathrm{yr} \mathrm{BP})\end{array}$ \\
\hline $54-55$ & G. ruber, G. sacculifer + other planktic foram & 17 & Poz-34066 & 3485 & 35 & $2755(2854) 2953$ \\
$78-79$ & G. ruber, G. sacculifer & 15 & SacA 21676 & 4935 & 30 & $4629(4825) 4825$ \\
$114-116$ & G. ruber, G. sacculifer + other planktic foram & 18.6 & Poz-34031 & 7760 & 60 & $7685(7940) 7940$ \\
$140-142$ & G. ruber, G. sacculifer + other planktic foram & 18 & Poz-34067 & 8500 & 50 & $8419(8716) 8716$ \\
\hline
\end{tabular}

A key location for the presence of slope-failure scars is the toe of the continental slope along the whole margin (Dan et al., 2010). Deep-towed side scan sonar images provide mor- phological details of these features and show numerous small landslide scars with a relatively fresh appearance, which are not or are scarcely covered by hemipelagic draping, with 
A
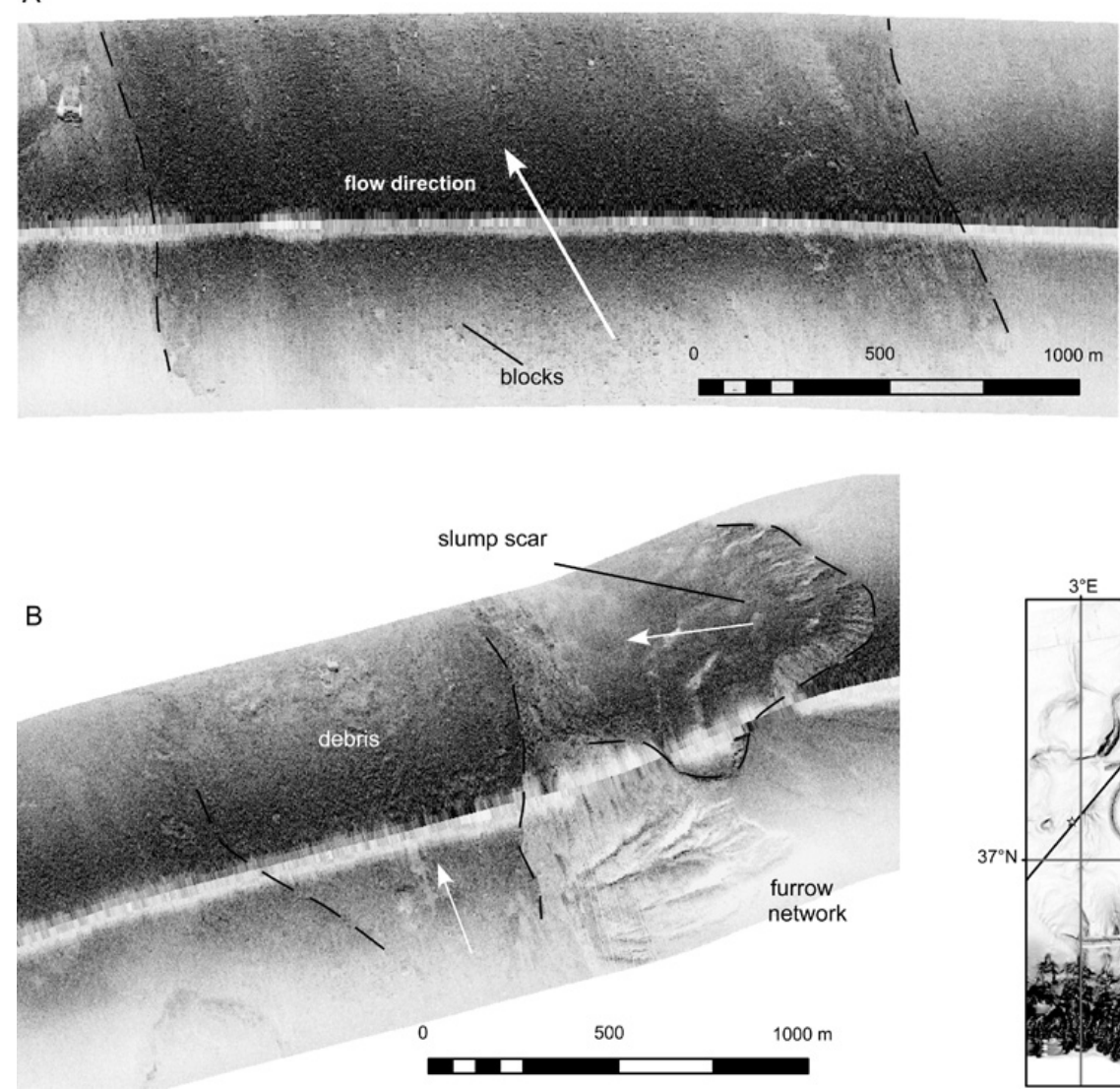
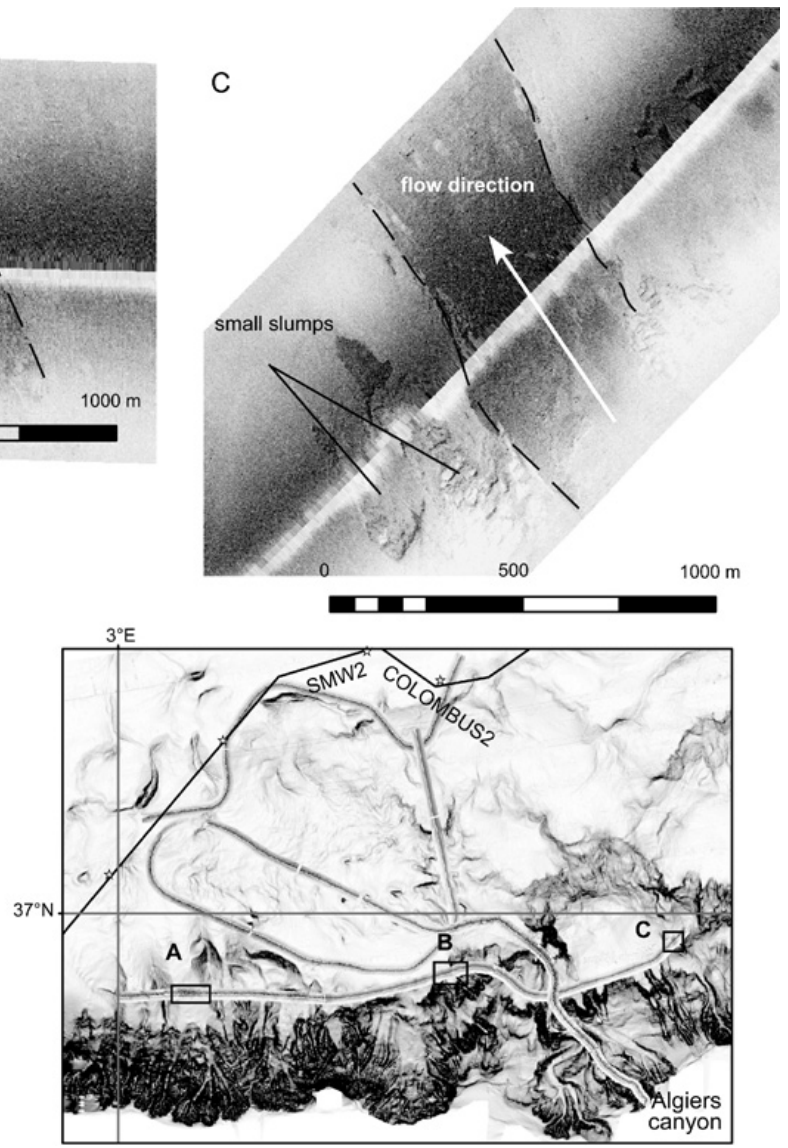

Fig. 3. Bathymetric gradient map (lower right panel) of the Algiers canyon with navigation track of side-scan sonar (SAR, light grey) and location of SMW2 (oriented SW-NE) and COLOMBUS2 (oriented W-E, U-shaped) submarine cables, where stars represent points of cable break (the map corresponds roughly to Zone 1 in Fig. 2). Three SAR images show evidence of seafloor destabilisation and erosion at the foot of the continental slope. Evidence of channelized erosion with longitudinal furrows, small sediment blocks and comet-like structures is visible in (A) and in the central part of (C). Erosion and accumulation of debris are testified by the seafloor scars and the rough backscatter in the associated deposits in $(\mathbf{B})$ and $(\mathbf{C})$ (on the left).

associated decametric to hectometric-sized blocks and debris accumulations (Fig. 3). Also, the slope scarps described above are affected by numerous landslide scars. For example, deep-towed side-scan sonar reveals a 1500-m wide and less than 30-m high landslide scar with an accumulation of fractured sediment at its foot, suggesting a short runout distance (Fig. 4a).

\subsection{Cable breaks}

Six offshore telecommunication cables cross the study area. Four cables run roughly parallel to the coastline connecting Europe to the Middle East: COLOMBUS2, FLAG, SEAME-WE3 (SMW3) and COLOMBUS3 (from the most proximal to the most distal). Two other cables cross the study area S-N or obliquely from SW to NE and are connected to Algeria $15 \mathrm{~km}$ west of Algiers: Algiers-Palma (ALPAL2), perpendicular to the shoreline, and Algiers-Marseille, SEAME-WE2 (SMW2; Fig. 1).
Only the most distal cable, COLOMBUS3, located at more than $80 \mathrm{~km}$ of the Algerian coast, remained operational after the 2003 Boumerdès earthquake (Van Oudheusden, 2003; ICPC, 2009). The three other "shore-parallel" cables (SMW3, FLAG, COLOMBUS2) were broken in 11, 3 and 6 points, respectively (Fig. 1), with a delay for the time of first break after the earthquake, which increases in the offshore direction (Table 1). The SMW2 cable was broken at seven locations in all physiographic domains, ranging from the upper slope to the distal abyssal plain, and it was the first cable to break only $36 \mathrm{~min}$ after the earthquake. Finally, the western-most cable, ALPAL2, was broken at a single location in the abyssal plain $3 \mathrm{~h}$ and $48 \mathrm{~min}$ after the earthquake. The ALPAL2 cable break represents the only case with an unequivocal association of cable break time and location; for all the other cable breaks, the time of first rupture cannot be associated with a specific location, but it has to be chosen among several options (Fig. 5). In two cases the ships performing submarine cable reparations found the 


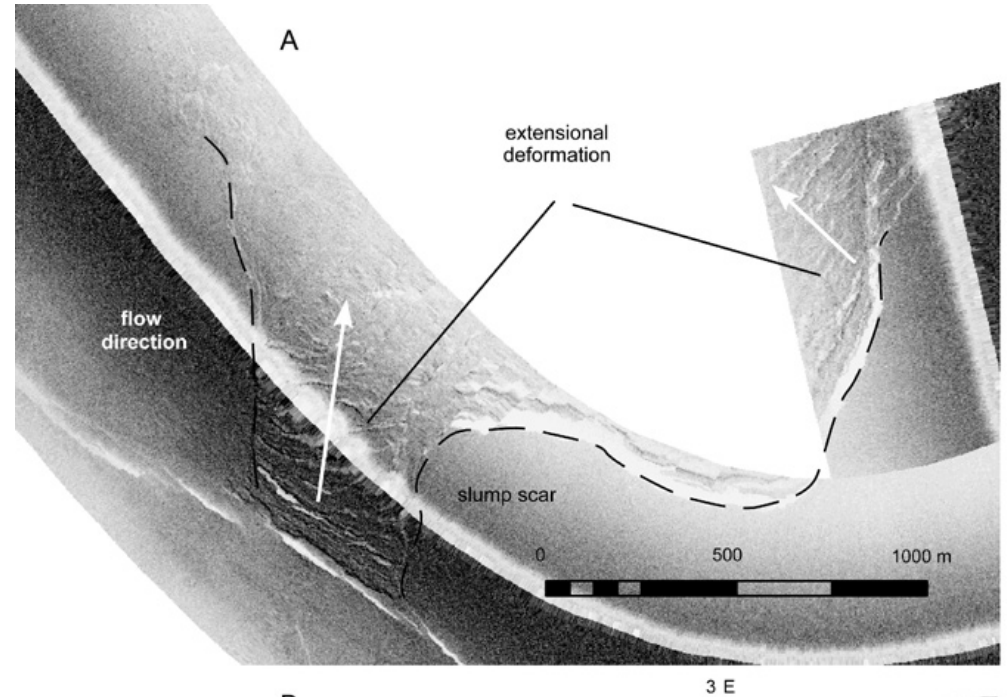

B

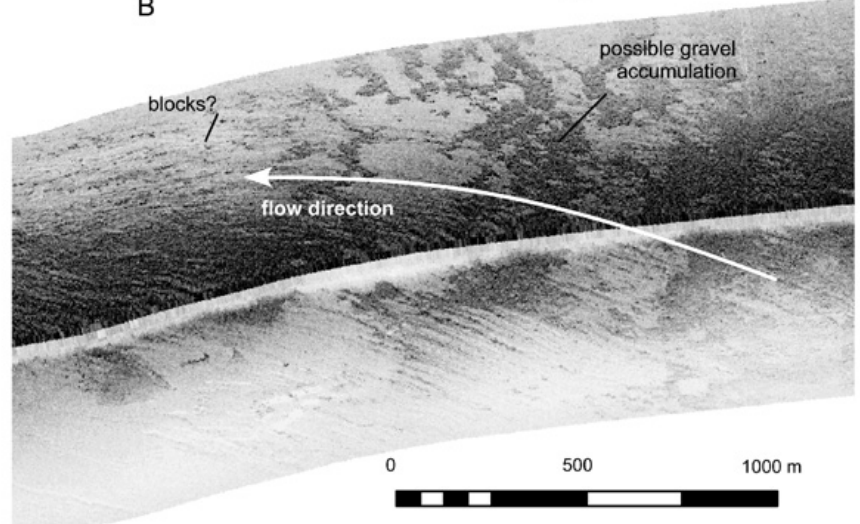

C
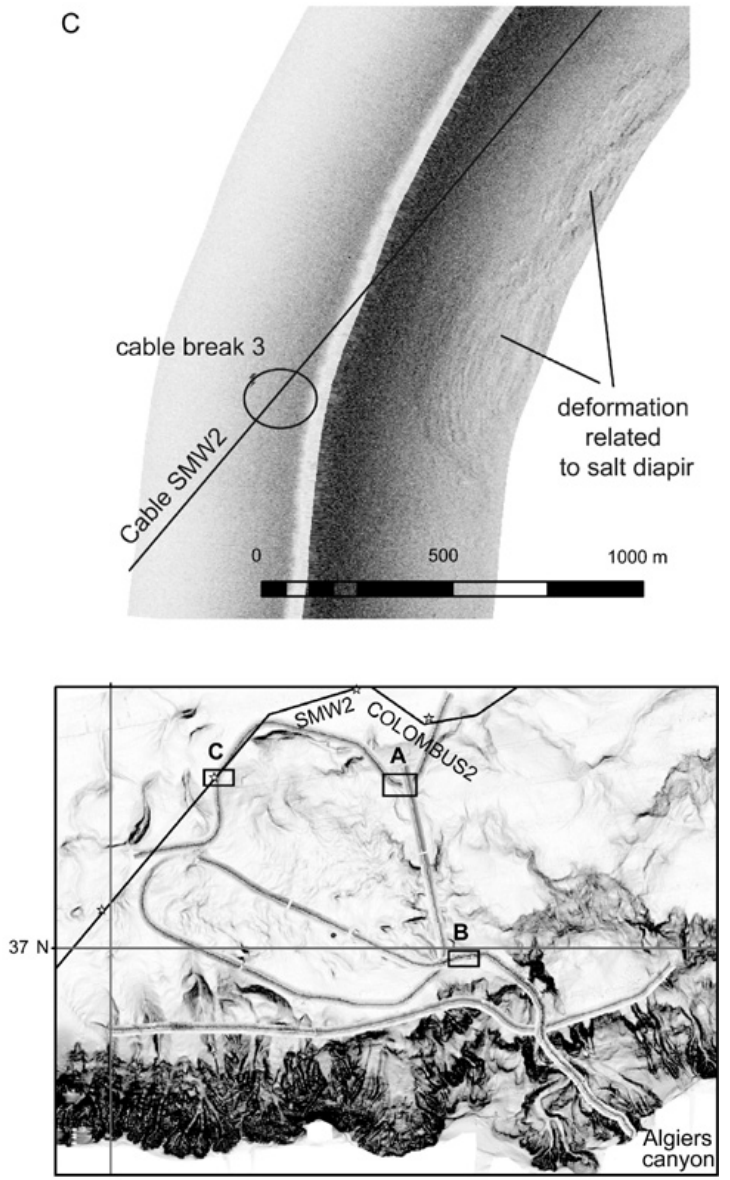

Fig. 4. Bathymetric gradient map (lower right panel) of the Algiers canyon with navigation track of side-scan sonar (SAR, light grey) and location of SMW2 (oriented SW-NE) and COLOMBUS2 (oriented W-E, U-shaped) submarine cables, where stars represent points of cable break. Two SAR images show evidence of intense sediment reworking in distal areas of the continental rise: (A) sharp slump scar with extensional deformation of sediment on the offshore flank of scarp S2 (the map corresponds roughly to Zone 1 in Fig. 2); (B) longitudinal furrows and patches of alternating light and dark backscatter representing likely bedforms and blocks along the axis of the Algiers turbiditic channel. (C) SAR image showing smooth seafloor morphology in the vicinity of cable break n. 3 with evidence of seafloor deformation due to the presence of a salt diapir.

cables displaced offshore compared with the expected location: (1) the cable FLAG was found $3.7 \mathrm{~km}$ NE of cable break point $\mathrm{n} .14$, ca. $1 \mathrm{~km}$ north of the inferred location of the cable at its point; (2) the cable COLOMBUS 2 was found some $5 \mathrm{~km}$ north of the cable route, between cable break points 12 and 13.

The cable breaks occurred in four distinct zones of the central Algerian margin separated by areas where cable breaks were not reported (Fig. 2): Zone 1 between $2^{\circ} 50^{\prime}$ and $3^{\circ} 30^{\prime}$ longitude $\mathrm{E}$, at the base of the slope and in the "proximal" abyssal plain in the continuity of the Algiers canyon; Zone 2 between $2^{\circ} 53^{\prime}$ and $3^{\circ} 25^{\prime} \mathrm{E}$ in the distal abyssal plain offshore the Algiers sector; Zone 3 between $3^{\circ} 35^{\prime}$ and $3^{\circ} 35^{\prime} \mathrm{E}$, only in the distal abyssal plain at the center of the study area; Zone 4 between $4^{\circ} 00^{\prime}$ and $4^{\circ} 35^{\prime} \mathrm{E}$, in the abyssal plain downslope of the Dellys and Sebaou canyons. The submarine cables are not visible in SAR images, and in some cases no obvious feature associated with cable breaks is detectable. For example, in Fig. 4c, only the sediment disturbance induced by the presence of a salt diapir is visible.

\subsection{Turbiditic systems and inferred sediment pathways}

The analysis of the morphology of the central Algerian turbiditic systems may help disentangle the sequence of events and identify the indirect consequences of the 2003 Boumerdès event offshore. High backscatter reflectivity suggests the presence of coarse sediments at the seafloor deposited along canyon axes (Fig. 2) and possibly recent activity of gravity flows. For example, in the western part of the study area, the axes of some canyons show fresh erosional furrows and plurimetric blocks (Fig. 3a-c), whereas 


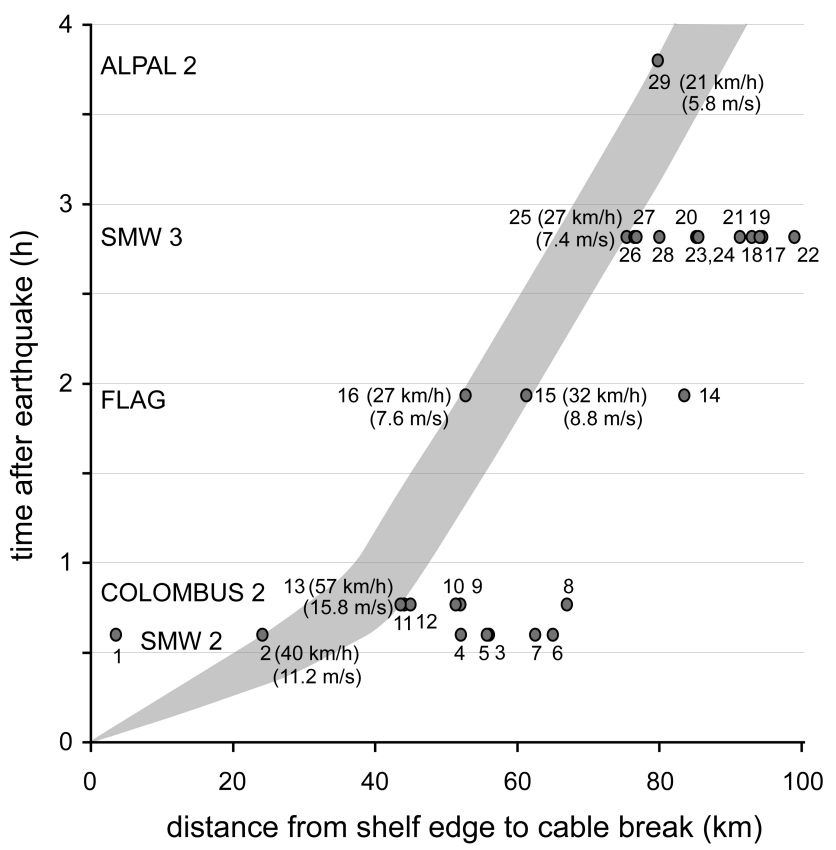

Fig. 5. Distance of cable breaks from the shelf edge plotted against the time of cable breaks after the Boumerdès 2003 earthquake. The distance is measured along the path of turbidity flows inferred from morphology and sketched in Fig. 2 above (dashed blue lines). The estimate of turbidity flow velocity is possible only with the assumption that the time of each cable break corresponds to the shortest distance from the shelf edge, with the exception of cable break 1 . See text for discussion.

other canyons (or tributary canyons) seem to be draped by fine sediments without evidence of erosion.

In the area offshore Algiers, the continental slope is incised by several canyons and gullies. Four main canyons are particularly developed between the bay of Algiers and Boumerdès based on high backscatter reflectivity (Fig. 2). The largest canyon is the Algiers canyon with two sinuous tributaries in its upper reach, a maximum relief of $600 \mathrm{~m}$, and a submarine valley oriented $\mathrm{E}-\mathrm{W}$ with a well-developed sedimentary ridge with a 20 to $50 \mathrm{~m}$ relief over the seafloor, possibly confined by the $\mathrm{S} 2$ scarp. Turbidity currents in provenance from the Algiers canyon and the three other canyons to the west probably overflow on the ridge towards the north in the direction of a series of cable breaks at the northern edge of Zone 1. Turbidity currents extend to the distal area, resulting in great sediment dispersion with local confinement between salt diapirs and walls. At the base of the Algiers canyon, a side-scan sonar image shows erosional furrows indicating the flow direction and perpendicular structures that could be interpreted as pebble or gravel waves, evidence of a high energy regime at this location (Fig. 4b).

Between Boumerdès and Dellys (south of Zone 3, Fig. 2), cable breaks are limited to the distal abyssal plain. Two canyons and the western branch of the Sebaou canyon are

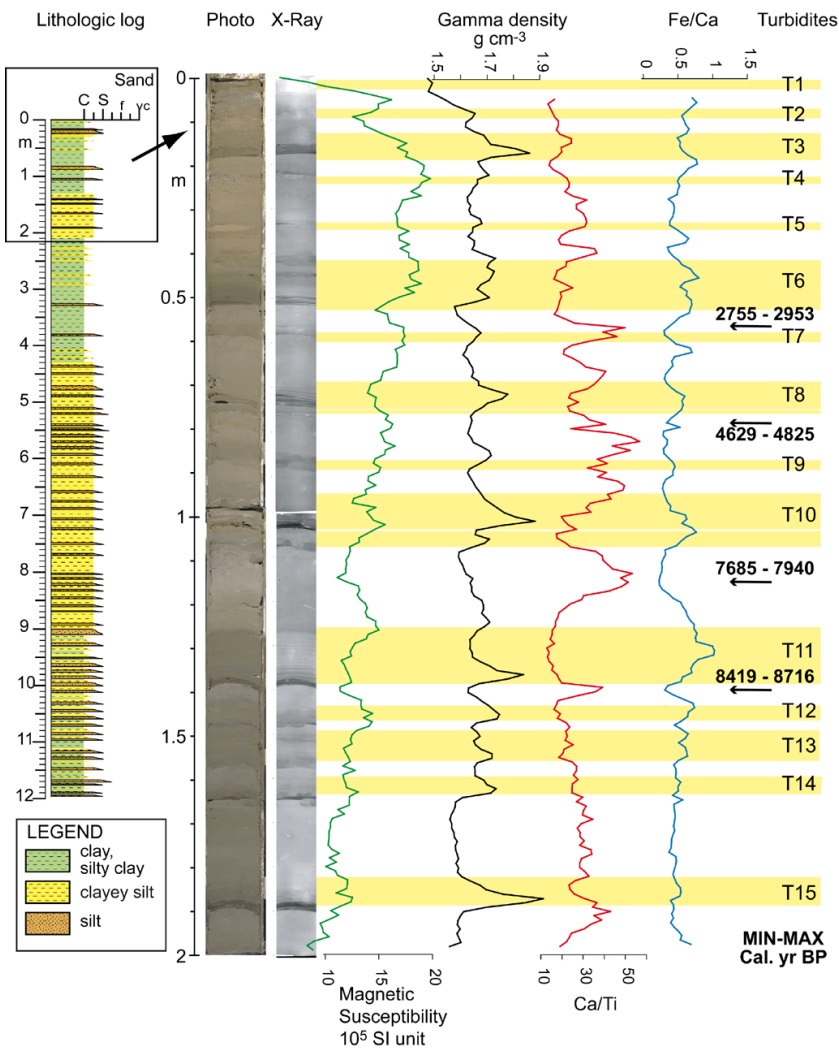

Fig. 6. Lithologic log of sediment core PSM-KS23 from the distal area of the Algiers turbiditic system in $2775 \mathrm{~m}$ water depth. Note the contrast between the closely spaced thin turbidites at the base of the core and the more widely spaced turbidites in the upper part. On the right: detail of the 2 upper meters of the core. The identification of turbidites is based on the comparison of photo and X-ray images of the sediment core, magnetic susceptibility, gamma density and XRF elemental ratios $\mathrm{Ca} / \mathrm{Ti}$ (proxy for carbonate production, with high values in hemipelagic intervals), and $\mathrm{Fe} / \mathrm{Ca}$ (detrital proxy, with high values in the turbidites). The radiocarbon ages show that during the Holocene the time interval between two adjacent turbidites is in the order of about $800 \mathrm{yr}$.

directed to the north in this sector, but apparently no strong turbidity current passed northwards in 2003, because cables COLOMBUS2 and SMW2 are intact here.

Finally, Zone 4 west of Dellys is characterised by the presence of three canyons with high-backscatter along their axis (the Sebaou canyon, the Dellys canyon and another immediately to the east), while the other canyons to the east appear subdued in morphology and less reflective (Fig. 2). Cable breaks are aligned with the three reflective canyons. Other morphological features suggest active sediment transport and erosion along these canyons and support the interpretation of an efficient transport of turbidity currents: in the distal part of the Dellys canyon, three chutes show an abrupt change in bathymetry of 70,120 and $200 \mathrm{~m}$ respectively from the canyon floor; along the distal part of the Sebaou canyon, a set of well-developed ridges and scours with a relief exceeding 
$40 \mathrm{~m}$ is a strong evidence for significant erosion (bathymetric profiles in Dan-Unterseh et al., 2011). The source area of the main turbidity currents appears to have originated from the Dellys and Sebaou canyons, while the easternmost canyons likely gave only minor contributions because of the lack of cable breaks along their trajectories.

\subsection{Turbidite deposits}

Numerous cores have been collected on the continental slope, at its base, and along major scarps (Giresse et al., 2009; DanUnterseh et al., 2011). These cores show typical sedimentary facies resulting from gravity processes (submarine landslides and turbidites). At the foot of the slope, cores sampled the proximal accumulation of turbidite currents with amalgamated sandy/silty beds, where hemipelagic intervals are generally not preserved, and it is thus difficult to reconstruct the chronology of turbidite beds. In more distal locations, the presence of alternating turbidite beds with hemipelagites representing background sediment accumulation allows to establish a time framework for the turbidites, even if particular caution must be taken to make a distinction between turbidite and hemipelagite beds (e.g. Gràcia et al., 2010).

Sediment core PSM-KS23 is the most distal core collected in the Algiers area at $37^{\circ} 27.093^{\prime} \mathrm{N}-002^{\circ} 59.526^{\prime} \mathrm{E}$ in $2775 \mathrm{~m}$ water depth (Fig. 6). Its location, close to one of the distal cable breaks of the 2003 Boumerdès event, attests that turbidity currents reached this area in 2003 (Fig. 2). The core is $11.95 \mathrm{~m}$ long, and it is composed of a succession of turbidite deposits separated by hemipelagic mud. In the lithologic log the turbidite beds are characterized by very fine sand and silt intervals $1-15 \mathrm{~cm}$ thick. The distance between turbidites is variable, but it averages $10-20 \mathrm{~cm}$ from the core top down to about $9 \mathrm{~m}$, then decreases to about $5-10 \mathrm{~cm}$ in the lower part of the core, with closely spaced, thin bedded turbidites. The precise identification of turbidites is based on the observation of X-ray images and the comparison with gamma density curve (the base of turbidites usually correspond to high density values) and XRF elemental ratios (Fig. 6). $\mathrm{Fe} / \mathrm{Ca}$ is a proxy for the terrigenous component of the sediment (e.g. Arz et al., 1999), while $\mathrm{Ca} / \mathrm{Ti}$ shows peaks in carbonate content. As it has been found elsewhere, turbidites that originated in shallow water tend to be richer in $\mathrm{Fe}$ and poorer in Ca than hemipelagic interbeds (Rothwell et al., 2006); in our case we interpreted peaks of $\mathrm{Fe} / \mathrm{Ca}$ as turbidite beds, and high values of $\mathrm{Ca} / \mathrm{Ti}$ as hemipelagites. Offshore Algeria some of the turbidites present enrichments in reworked Foraminifera: contrary to other cases in the literature, there may be a relevant amount of carbonate also within some of the turbidites, making the distinction among hemipelagites and turbidites sometimes difficult.

The uppermost $2 \mathrm{~m}$ of sediment in core PSM-KS23 contain 15 silty turbidites (Fig. 6). In some cases (e.g. T6, T8 and T10, Fig. 6), we interpreted as a single turbiditic "event" several stacked silt layers without intervening hemipelagite.
Hemipelagic muds, characterized by a light colour and the presence of abundant Foraminifera, allow to obtain the age of the interfingered turbidite beds through radiocarbon dating on planktonic Foraminifera (Table 2). Four radiocarbon dates obtained in hemipelagic intervals of the upper $1.5 \mathrm{~m}$ of the core within the Holocene suggest an average recurrence interval of about $800 \mathrm{yr}$ between turbidites in this area (Fig. 6). At the top of the core, we identify a thin turbidite; however, it is not possible to interpret unequivocally this deposit as the result of the 2003 event, because the top of the Kullenberg core is often disturbed or not preserved.

\section{Discussion}

\subsection{Submarine impact of the 2003 earthquake on the central Algerian continental slope: evidence and uncertainties}

\subsubsection{Seafloor scarps}

Although scarps on land may represent the direct expression of an earthquake, in the subaqueous domain this evidence is more subdued by the dominance of sedimentation. Déverchère et al. (2010) show that there is no direct and convincing evidence that the fault responsible for the Boumerdès earthquake has a direct expression at the seafloor in the prolongation of the fault plane, which is at the base of the slope along the B1 scarp described in Déverchère et al. (2005). The scarps S1 to S3 presented in Fig. 2 were identified as anticlines with seismic-reflection data and likely express superficial deformation of blind thrust faults (Déverchère et al., 2005; Strzerzynski et al., 2010). Rather than being a direct expression of a single earthquake, these scarps are thought to represent the cumulative effect of deformation with shortening over ramp-flat trajectories of active faults at depth (Déverchère et al., 2005, 2010; Lofi et al., 2011).

Because of the tectonic over-steepening of their slope gradients, the scarps are preferential sites for submarine landslides (Cattaneo et al., 2010; Nouguès et al., 2010). Facilitated by the great slope gradient, instability is most likely triggered by soil acceleration leading to the liquefaction of thin silty layers interbedded in the dominant hemipelagic sediments (Dan et al., 2009; Nouguès et al., 2010).

\subsubsection{Submarine landslides}

Much evidence of submarine landslides is found along the Algerian margin, especially at the base of the slope. The slope failures show a large span of size and volume (e.g. Dan et al., 2010; Cattaneo et al., 2010). The apparent freshness of many slope failure scars and of the resulting blocks supports that these instabilities are recent. However, a precise age of each failure has proven elusive until today to ascertain with the available data, in particular in absence of pre- and post-event bathymetric survey (see, for example, the 
2002 Stromboli event case history in Chiocci et al., 2008). Although no direct evidence of a submarine landslide triggered by the 2003 earthquake is available, the soil acceleration of such an event is compatible with the sediment failure in areas where submarine landslides are present (Dan et al., 2009; Nouguès et al., 2010). Furthermore, it is possible that a submarine landslide, which probably originated along one of the seafloor scarps described above, is at the origin of cable breaks either directly or indirectly by transforming into a turbidity current, as proposed in the interpretation of the causal mechanisms for cable breaks in Fig. 2 (blue arrows).

\subsubsection{Turbidity currents}

Cable breaks caused by the 2003 turbidity currents show some differences from other known events. In other cases, for example the 1908 Messina event (Ryan and Heezen, 1965), the 1929 Grand Banks earthquake (Heezen and Ewing, 1952; Piper et al., 1999), the Orléansville 1954 event (Heezen and Ewing, 1955), and the 2006 event offshore Taiwan (Hsu et al., 2008), a small number of cables ruptured in sequence along a relatively straightforward path for turbidity currents, allowing a reconstruction of the velocity of turbidite current speed. This was also the case for the 1979 Nice airport event (Piper and Savoye, 1993), where, however, no earthquake was involved (Dan et al., 2007 and references therein).

Offshore Algeria, five cables were broken at so many different locations that the identification of a single turbidity flow path is impossible. The ruptures clearly occurred off at least two distinct turbiditic systems: the Algiers canyon (and three adjacent canyons) to the west, and the Sebaou and Dellys canyon to the east. A multi-source assumption is thus the easiest way to explain the wide geographic span of cable breaks, arguing for a multi-source ramp-type model of channelized system development (Reading and Richards, 1994). In any case, even when considering each system independently, the turbidity current path does not appear straightforward. There are two oddities in this pattern of cable breaks (Fig. 2): (1) cable FLAG remained surprisingly intact between Zones 1 and 2; (2) in the center of the study area only the distal cables SMW3 and FLAG broke, while the more proximal cables SMW2 and COLOMBUS2 remained untouched in this sector. Furthermore, the location of cable breaks does not correspond with the location where the damaged cables were recovered, which in two cases shifted some kilometers offshore. Also based on this last piece of evidence, cable breaks are attributed to the erosion action of turbidity currents. Several turbidity currents, all triggered by the 2003 earthquake, have apparently followed paths offshore along distinct turbiditic systems.

The path of turbidity currents following the 2003 Boumerdès event seems controlled by the complex morphology at the toe of the continental slope, where seafloor scarps S1-S3 could have played a major role (Fig. 2). For example, the Algiers canyon veers westward at the toe of the conti- nental slope following the seafloor scarp S2. In the Dellys area, between the base of the canyons and the scarp S1, a perched basin (Strzerzynski et al., 2010) has probably acted as a trap for turbidity currents, and the most likely path towards the ruptures of Zone 3 comes from the NE corner of Zone 1, in the distal reaches of the Algiers canyon. It remains in any case difficult to explain how turbidity currents may have impacted the cable SMW3 beyond the undamaged cable FLAG between Zone 1 and Zone 2, without invoking a difference in the strength of the two cables. The reduced number of breaks along cable FLAG, if compared with cable SMW3, might support this explanation (Fig. 2, Table 1). Unfortunately, SAR data at the location of cable breaks cannot help understand if FLAG had been buried at deeper depth than SMW3 cable to confirm this hypothesis.

A rough estimate of turbidity flow velocity is proposed in Fig. 5 by assuming the following: (1) the path of turbidity currents follows the main morphologic features identified at the seafloor and outlined in Fig. 2; (2) the time of each cable break corresponds to the shortest distance from the shelf edge (highlighted in the grey area), with the exception of cable break n. 1, which probably represents a local anomaly. Although the resulting turbidity flow velocities are overall comparable with other available case studies (see a review in Hsu et al., 2008), several problems remain. For example, it is necessary to assume a long trajectory following the Algiers canyon and submarine valley to obtain a reasonable flow velocity at cable break n. 29, but it is not possible to explain with the same turbidity flow the cable breaks n. 2 and 29 . Also, cable breaks 11-12 and 15-16, all relatively close and along similar trajectories, cannot be explained by the same turbidity flow, because they broke $46^{\prime}$ and $01: 56^{\prime}$ after the earthquake, respectively.

Finally, the comparison of the locations of potential sediment sources (the canyon heads) and the locations of cable ruptures supports the interpretation that turbidity flows were deflected eastwards (Fig. 2). This deflection could be the result of the Coriolis effect, which is well known to modify the deposition pattern of active deep-sea fans (Silva Jacinto et al., 2010).

\subsection{Potential reconstructions of paleoseismology with distal turbidites offshore the central Algerian margin}

As large earthquakes can generate regional turbidity currents, turbidite chronostratigraphy was demonstrated to be a powerful paleoseismological tool in both fast subduction zones (Adams, 1990; Goldfinger et al., 2003; Griggs, 2011) and slowly convergent margins (Gràcia et al., 2010). In order to discriminate earthquake-triggered from storm- or floodtriggered turbidites, such studies are based on synchronous deposits with independent sources over large areas. For a paleoseismological approach, it is necessary to sample large 
and regional turbidity events (triggered by large earthquakes) and to obtain age and stratigraphy of these accumulations.

The best record of large events along the Algerian margin is represented by distal turbidite deposits interbedded with hemipelagic intervals. In the area offshore Algiers, the preliminary chronostratigraphic results from core PSM-KS23 reveal that at least 11 turbidites were accumulated during the Holocene, with a mean recurrence interval of $792 \mathrm{yr}$ (Fig. 6). Although a paleoseismological approach based on a single core is not possible, the position of this core less than $5 \mathrm{~km}$ away from the cable breaks suggests that the sampled turbidites may be seismically triggered. It is also worth to note the following: (1) the mean recurrence interval of turbidites in core PSM-KS23 is of the same order as the mean 720-yr interval proposed by Meghraoui et al. (1988) from their paleoseismic investigation led on the El Asnam fault onshore, $\sim 250 \mathrm{~km} \mathrm{~W}-\mathrm{SW}$ from the Boumerdès earthquake area, and (2) large events in the eastern Algiers area are very rare over the last $1200 \mathrm{yr}$ according to historical records (Hamdache et al., 2010), supporting a possible causative link between a given earthquake shaking threshold and multi-source turbidity currents triggered at this place.

At least two main reasons prevent a more precise comparison between individual fault recurrences on land and turbidite bed occurrences offshore at this stage. First, active fault segments at different locations along the Algerian margin probably overlap in space (Domzig et al., 2006; YellesChaouche et al., 2006) and may significantly vary in maximum magnitude and strain rate. Second, in simplified seismologic models, the magnitude of earthquakes is proportional to the fault size and the strain accumulated since the previous earthquake (i.e. the time), resulting in a power law magnitude frequency distribution (Gutenberg and Richter, 1944). Even with these assumptions, however, these models fail to explain the great variations in recurrence intervals, thus leading to the emergence of a theory of stress transfer and stress interactions, where stress release on a fault can increase or decrease stress on a nearby fault, potentially triggering or retarding an earthquake, respectively (Chéry et al., 2001; Freed, 2005).

Additional radiocarbon dating on core PSM-KS23 and other distal cores offshore Algiers should allow us to refine the turbidite chronology and test their synchronicity in order to validate the hypothesis of a seismic trigger. The resulting earthquake calendar could allow to constrain the seismogenic behaviour of the main faults. A similar investigation is in progress on the adjacent margin segment of Kramis, offshore the El Asnam fault (western Algerian margin) and will allow a precise correlation with the onshore paleoseismology and a comparison with the Algiers area in order to discuss the stress transfers and interactions between the two margin segments.

\section{Conclusions}

On 21 May 2003, a magnitude 6.8 earthquake struck the central Algerian margin with an epicenter at the coastline and a pure reverse-type fault plane mechanisms. This event also triggered a tsunami wave that hit the Balearic Islands and was detected in tide gauges of the western Mediterranean. Offshore, the event caused the rupture of 5 out of the 6 telecommunication cables running across and along the central Algerian margin. Twenty-nine cable breaks occurred in physiographic domains ranging from the inner continental slope down to the abyssal plain. The cable breaks occurred between $36 \mathrm{~min}$ and $3 \mathrm{~h}$ and $48 \mathrm{~min}$ after the earthquake, over a distance of $150 \mathrm{~km}$ and as far as $70 \mathrm{~km}$ away from the coastline. The same cable was often affected by multiple breaks, preventing in most cases the exclusive identification of the time and site of each cable break. The cables were probably damaged by the passage of turbidity currents triggered by the earthquake. The location of submarine cable breaks supports evidence of a series of turbidity currents triggered synchronously along distinct turbiditic systems. The analysis of the morphology of the seafloor helps unravel the sediment gravity events and suggests a likely scenario of the offshore impact of the 2003 earthquake.

Two main cable break zones correspond clearly to the prolongation of canyons cutting the central Algerian margin: the Algiers canyon to the west, and the Sebaou and Dellys canyons to the east. The likely path of turbidity currents, reconstructed according to the morphology, side-scan sonar images and the location of submarine cable breaks, appears to be strongly dependent on the roughness and irregularities of the seafloor. Several W-E oriented tectonic scarps shape the morphology of the central Algerian slope, outlining some perched slope basins. The scarps constitute areas more prone to sediment failure, a potential additional source for cable breaks. Seafloor scarps have deflected turbidity flow paths, while perched basins may have acted as a trap for turbidites, preventing a further expansion of turbidity flows offshore, at least in the central part of the study area. A systematic deflection towards the east (right) of inferred turbidity flows is probably the expression of the Coriolis effect.

The signature of the 2003 event along the canyons, submarine valleys and scarps is rather erosional, and it is thus difficult to identify and distinguish the traces of the 2003 earthquake from other previous events. In the submarine realm, direct traces of earthquakes and subsequent sediment gravity flows are difficult to document in proximal areas (continental slope), especially because of the erosive nature of the earthquake-triggered processes. In the distal area of the Algiers canyon, thin turbidite beds interfingered with hemipelagic deposits rich in Foraminifera represent a sedimentary record potentially linked to earthquakes. As such, turbidite beds constitute the best potential target for paleoseismic reconstructions in the submarine domain. Preliminary results on a sediment core in $2775 \mathrm{~m}$ water depth 
indicate a mean recurrence time of about $800 \mathrm{yr}$ between turbidites during the Holocene, in rough agreement with paleoseismological data available on one individual fault on land, and with the scarce occurrence of strong historical earthquakes at the scale of the segments of the Algerian margin. These results support the view that large coastal earthquakes in Algeria may represent the main triggering mechanism at the origin of large turbidity flows in the deep Algerian basin, at least during sea-level high stands, even if further work on synchronous turbiditic series along distinct sediment dispersal systems is necessary to achieve a sound reconstruction of paleoseismology from the offshore domain of Algeria.

Acknowledgements. The authors thank captains and crews of cruises Maradja 2003 and Maradja2/Samra 2005 (R/V Le Surôtt) and Prisme 2007 (R/V L'Atalante). We acknowledge N. Sultan R. Silva Jacinto and T. Lateb for discussions and the Editors of the volume for their patience. Stimulating comments by reviewers N. Mitchell, E. Park and Guest Editor E. Gràcia enhanced the manuscript. We acknowledge financial support of ANR projects ISIS and DANACOR. Funding for radiocarbon dates was provided by INSU-CNRS Artemis. We dedicate this work to the memory of Bruno Savoye who had launched this project and was an inspiring leader for the understanding of turbiditic processes.

Edited by: E. Gràcia

Reviewed by: N. Mitchell and E. Parker

\section{References}

Adams, J.: Paleoseismicity of the Cascadia subduction zone: evidence from turbidites off Oregon-Washington margin, Tectonophysics, 9, 569-583, 1990.

Alasset, P.-J., Hébert, H., Maouche, S., Calbini, V., and Meghraoui, M.: The tsunami induced by the 2003 Zemmouri earthquake (MW $=6.9$, Algeria): modelling and results, Geophys. J. Int., 166, 213-226, 2006.

Ambraseys, N. N.: The El Asnam (Algeria) earthquake of 10 October 1980: conclusions drawn from a field study, Q. J. Eng. Geol. London, 14, 143-148, 1981.

Ambraseys, N. and Vogt, J.: Material for the investigation of the seismicity of the region of Algiers, European Earthquake Engineering, 3, 16-29, 1988.

Arz, H. W., Patzold, J., and Wefer, G.: Climatic changes during the last deglaciation recorded in sediment cores from the northeastern Brazilian Continental Margin, Geo-Marine Letters, 19, 209218, 1999.

Avouac, J.-R., Meyer, B., and Tapponier, P.: On the growth of normal faults and the existence of flats and ramps along the El Asnam active fold and thrust system, Tectonics, 11, 1-11, 1992.

Ayadi, A., Maouche, S., Harbi, A., Meghraoui, M., Beldjoudi, H., Ousadou, F., Mahsas, A., Benouar, D., Heddar, A., Rouchiche, Y., Kherroubi, A., Frogneux, M., Lammali, K., Benhamouda, F., Sebaï, A., Bourouis, S., Alasset, J. P., Aoudia, A., Cakir, Z., Merahi, M., Nouar, O., Yelles, A., Bellik, A., Briole, P., Charade, O., Thouvenot, F., Semmane, F., Ferkoul, A., Deramchi, A., and
Haned, S. A.: Strong Algerian earthquake strikes near capital city, EOS Trans. AGU, 84, 561-568, 2003.

Ayadi, A., Dorbath, C., Ousadou, F., Maouche, S., Chikh, M., Bounif, M. A., and Meghraoui, M.: Zemmouri earthquake rupture zone (Mw 6.8, Algeria): Aftershocks sequence relocation and 3D velocity model, J. Geophys. Res., 113, B09301, doi:10.1029/2007JB005257, 2008.

Baratta, M.: La Catastrofe Sismica Calabro Messinese (28 Dicembre 1908), Presso la Soc. Geogr. It., 1910.

Benouar, D.: The seismicity of Algeria and Adjacent Regions During the Twentieth Century, PhD, Imperial College of Science, Technology and Medicine, University of London, London, 712, 1993.

Bounif, A., Dorbath, C., Ayadi, A., Meghraoui, M., Beldjoudi, H., Laouami, N., Frogneux, M., Slimani, A., Alasset, P., Kherroubi, A., Ousadou, F., Chikh, M., Harbi, A., Larbes, S., and Maouche, S.: The 21 May 2003 Zemmouri (Algeria) earthquake Mw 6.8: Relocation and aftershock sequence analysis, Geophys. Res. Lett., 31, L19606, doi:10.1029/2004GL020586, 2004.

Calais, E., DeMets, C., and Nocquet, J.-M.: Evidence for a post3.16 Ma change in Nubia-Eurasia plate motion, Earth Planet. Sc. Lett., 216, 81-92, doi:10.1016/S0012-821X(03)00482-5, 2003.

Carter, L., Burnett, D., Drew, S., Marle, G., Hagadorn, L., BartlettMcNeil, D., and Irvine, N.: Submarine Cables and the Oceans - Connecting the World, UNEP-WCMC Biodiversity Series No. 31, ICPC/UNEP/UNEP-WCMC, 2009.

Cattaneo, A., Babonneau, N., Dan, G., Déverchère, J., Domzig, A., Gaullier, V., Lepillier, B., Lépinay, B. M., Nouguès, A., Strzerzynski, P., Sultan, N., and Yelles, K.: Submarine Landslides Along the Algerian Margin: A Review of Their Occurrence and Potential Link with Tectonic Structures, in: Submarine Mass Movements and Their Consequences, edited by: Mosher, D., Moscardelli, L., Baxter, C. D. P., Urgeles, R., Shipp, R. C., Chaytor, J. D., and Lee, H. J., Adv. Nat. Technol. Haz., Springer, 28, 515-525, 2010.

Chéry, J., Merkel, S., and Bouissou, S.: A physical basis for time clustering of large earthquakes, B. Seismol. Soc. Am., 91, 16851693, 2001.

Chiocci, F. L., Romagnoli, C., Tommasi, P., and Bosman, A.: The Stromboli 2002 tsunamigenic submarine slide: Characteristics and possible failure mechanisms, J. Geophys. Res., 113, B10102, doi:10.1029/2007JB005172, 2008.

Dan, G., Sultan, N., and Savoye, B.: The 1979 Nice harbour catastrophe revisited: Trigger mechanism inferred from geotechnical measurements and numerical modelling, Mar. Geol., 245, 40-64, 2007.

Dan, G., Sultan, N., Savoye, B., Déverchère, J., and Yelles, K.: Quantifying the role of sandy-silty sediments in generating slope failures during seismic shaking: Example from the Algerian margin, Int. J. Earth Sci., 98, 769-789, doi:10.1007/s00531-0080373-5, 2009.

Dan, G., Sultan, N., Cattaneo, A., Déverchère, J., and Yelles, K.: Mass-transport deposits on the Algerian Margin (Algiers Area): Morphology, Lithology and Sedimentary Processes, in: Submarine Mass Movements and Their Consequences, edited by: Mosher, D., Moscardelli, L., Baxter, C. D. P., Urgeles, R., Shipp, R. C., Chaytor, J. D., and Lee, H. J., Adv. Nat. Technol. Haz., Springer, 28, 527-539, 2010. 
Dan-Unterseh, G., Savoye, B., Gaullier, V., Cattaneo, A., Déverchère, J., Yelles, K., and MARADJA 2003 Team: Algerian margin sedimentation patterns (Algiers area, south-western Mediterranean), in: Mass-Transport Deposits in Deepwater Settings, edited by: Shipp, R. C., Weimer, P., and Posamentier, H. W., AAPG-SEPM Special Volume 96, 69-84, 2011.

Dean, S. M., McNeill, L. C., Henstock, T. J., Bull, J. M., Gulick, S. P. S., Austin Jr., J. A., Bangs, N. L. B., Djajadihardja, Y. S., and Permana, H.: Contrasting Décollement and Prism Properties over the Sumatra 2004-2005 Earthquake Rupture Boundary, Science, 329, 207-210, doi:10.1126/science.1189373, 2010.

Delouis, B., Vallée, M., Meghraoui, M., Calais, E., Maouche, S., Lammali, K., Mahsas, A., Briole, P., Benhamouda, F., and Yelles, K.: Slip distribution of the 2003 Boumerdes-Zemmouri earthquake, Algeria, from teleseismic, GPS, and coastal uplift data, Geophys. Res. Lett., 31, L18607, doi:10.1029/2004GL020687, 2004.

Déverchère, J., Yelles, K., Domzig, A., Mercier de Lépinay, B., Bouillin, J. P., Gaullier, V., Bracène, R., Calais, E., Savoye, B., Kherroubi, A., Le Roy, P., Pauc, H., and Dan, G.: Active thrust faulting offshore Boumerdes, Algeria, and its relations to the 2003 Mw 6.9 earthquake, Geophys. Res. Lett., 32, L04311, doi:10.1029/2004GL021646, 2005.

Déverchère, J., Mercier de Lépinay, B., Cattaneo, A., Strzerzynski, P., Calais, E., Domzig, A., and Bracène, R.: Comment on "Zemmouri earthquake rupture zone (Mw 6.8, Algeria): Aftershocks sequence relocation and 3D velocity model" by Ayadi et al., J. Geophys. Res., 115, B04320, doi:10.1029/2008JB006190, 2010.

Domzig, A., Yelles, K., Le Roy, C., Déverchère, J., Bouillin, J.-P., Bracène, R., Mercier de Lépinay, B., Le Roy, P., Calais, E., Kherroubi, A., Gaullier, V., Savoye, B., and Pauc, H.: Searching for the Africa-Eurasia Miocene boundary offshore western Algeria (MARADJA'03 cruise), Comptes Rendus Geosciences, 338, 8091, 2006.

Einsele, G., Chough, S. K., and Shiki, T.: Depositional events and their records - An introduction, Sediment Geol., 104, 1-9, 1996.

El-Robrini, M., Genesseaux, M., and Mauffret, A.: Consequences of the El-Asnam Earthquake: Turbidity Currents and Slumps on the Algerian Margin (Western Mediterranean), Geo.-Mar. Lett., 5, 171-176, 1985.

Freed, A. M.: Earthquake triggering by static, dynamic, and postseismic stress transfer, Annu. Rev. Earth Pl. Sc., 33, 335-367, doi:10.1146/annurev.earth.33.092203.122505, 2005.

Furumura, T., Takemura, S., Noguchi, S., Takemoto, T., Maeda, T., Iwai, K., and Padhy, S.: Strong ground motions from the 2011 off the Pacific Coast of Tohoku, Japan $(\mathrm{Mw}=9.0)$ earthquake obtained from a dense nationwide seismic network, Landslides, 8, 333-338, doi:10.1007/s10346-011-0279-3, 2011.

Gaullier, V. and Vendeville, B.: Salt tectonics driven by sediment radation: Part II - Radial spreading of sedimentary lobes prograding above salt, AAPG Bull., 89, 1081-1089, 2005.

Giresse, P., Pauc, H., Déverchère, J., and Maradja Shipboard Scientific Party: Sedimentary processes and origin of sediment gravityflow deposits on the western Algerian margin during late Pleistocene and Holocene, Mar. Petrol. Geol., 26, 695-710, 2009.

Goldfinger, C., Nelson, C. H., Johnson, J. E., and Party, S. S.: Holocene earthquake records from the Cascadia subduction zone and northern San Andreas Fault based on precise dating of offshore turbidites, Annu. Rev. Earth. Pl. Sc., 31, 555-577, 2003.
Gràcia, E., Vizcaino, A., Escutia, C., Asioli, A., Rodés, A., Pallàs, R., Garcia-Orellana, J., Lebreiro, S., and Goldfinger, C.: Holocene earthquake record offshore Portugal (SW Iberia): testing turbidite paleoseismology in a slowconvergence margin, Quaternary Sci. Rev., 29, 1156-1172, doi:10.1016/j.quascirev.2010.01.010, 2010.

Griggs, G. B.: The first ocean floor evidence of great Cascadia earthquakes, EOS, 92, 325-326, 2011.

Gutenberg, B. and Richter, C. F.: Frequency of earthquakes in California, B Seismol. Soc. Am., 34, 185-188, 1944.

Hamdache, M., Pelaez, J. A., Talbi, A., and Casado, C. L.: A Unified Catalog of Main Earthquakes for Northern Algeria from A.D. 856 to 2008, Seismol. Res. Lett., 81, 732-739, doi:10.1785/gssrl.81.5.732, 2010.

Harbi, A., Maouche, S., Ousadou, F., Rouchiche, Y., YellesChaouche, A., Merahi, M., Heddar, A., Nouar, O., Kherroubi, A., Beldjoudi, H., Ayadi, A., and Benouar, D.: Macroseismic Study of the Zemmouri Earthquake of 21 May 2003 (Mw 6.8, Alegeria), Earthquake Spectra, 23, 315-332, 2007.

Harbi, A., Meghraoui, M., and Maouche, S.: The Djidjelli (Algeria) earthquakes of 21 and 22 August 1856 (I $\mathrm{I}_{0}$ VIII, IX) and related tsunami effects Revisited, J. Seismol., 15, 105-129, 2011.

Heezen, B. C. and Ewing, M.: Turbidity Currents and Submarine Slumps, and the 1929 Grand-Banks Earthquake, Am. J. Sci., 250, 849-873, 1952.

Heezen, B. C. and Ewing, M.: Orléansville earthquake and turbidity currents, AAPG Bulletin, 39, 2505-2514, 1955.

Hsu, S.-K., Kuo, J., Lo, C.-L., Tsai, C.-H., Doo, W.-B., Ku, C.Y., and Sibuet, J.-C.: Turbidity Currents, Submarine Landslides and the 2006 Pingtung Earthquake off SW Taiwan, Terr. Atmos. Ocean. Sci., 19, 767-772, doi:10.3319/TAO.2008.19.6.767(PT), 2008.

ICPC (International Cable Protection Committee): Critical Infrastructure - Submarine Telecommunications Cables. A presentation on the critical role of submarine cables to the global economy, available at: http://www.iscpc.org/, 2009.

Kherroubi, A., Déverchère, J., Yelles, A., Mercier de Lépinay, B., Domzig, A., Cattaneo, A., Bracène, R., Gaullier, V., and Graindorge, D.: Recent and active deformation pattern off the easternmost Algerian margin, Western Mediterranean Sea: New evidence for contractional tectonic reactivation, Mar. Geol., 261, 17-32, 2009.

Koketsu, K., Yokota, Y., Nishimura, N., Yagi, Y., Miyazaki, S., Satake, K., Fujii, Y., Miyake, H., Sakai, S., Yamanaka, Y., and Okada, T.: A unified source model for the 2011 Tohoku earthquake, Earth Planet. Sci. Lett., 310, 480-487, doi:10.1016/j.epsl.2011.09.009, 2011.

Lofi, J., Déverchère, J., Gaullier, V., Gillet, H., Gorini, C., Guennoc, P., Loncke, L., Maillard, A., Sage, F., and Thinon, I.: Seismic Atlas of The Messinian Salinity Crisis markers in the Mediterranean and Black Seas, co-Edition Mémoires Société Géologique de France (nouvelle série) et Commission for the Geological Map of the World, 179, 72 pp., 1CD, ISBN 2-85363-097-8, 2011.

Mahsas, A., Lammali, K., Yelles, K., Calais, E., Freed, A. M., and Briole, P.: Shallow afterslip following the 2003 May 21, Mw = 6.9 Boumerdes earthquake, Algeria, Geophys. J. Int., 172, 155166, 2008.

Meghraoui, M., Jaegy, R., Lammali, K., and Albarède, F.: Late Holocene earthquake sequences on the El Asnam (Algeria) thrust 
fault, Earth Planet. Sc. Lett., 90, 187-203, 1988.

Meghraoui, M., Maouche, S., Chemaa, B., Cakyr, Z., Aoudia, A., Harbi, A., Alasset, P., Ayadi, A., Bouhadad, Y., and Benhamouda, F.: Coastal uplift and thrust faulting associated with the $\mathrm{Mw}=6.8$ Zemmouri (Algeria) earthquake of 21 May, 2003, Geophys. Res. Lett., 31, L19605, doi:10.1029/2004GL020466, 2004.

Migeon, S., Weber, O. Faugères, J.-C., and Saint-Paul, J.: SCOPIX: A new X-ray imaging system for core analysis, Geo.-Mar. Lett., 18, 251-255, 1999.

Nouguès, A., Sultan, N., Cattaneo, A., Dan, G., and Yelles, K.: Detailed Analysis of a Submarine Landslide (SAR-27) in the Deep Basin Offshore Algiers (Western Mediterranean), in: Submarine Mass Movements and Their Consequences, edited by: Mosher, D., Moscardelli, L., Baxter, C. D. P., Urgeles, R., Shipp, R. C., Chaytor, J. D., and Lee, H. J., Adv. Nat. Technol. Haz., Springer, 28, 541-552, 2010.

Piper, D. J. W. and Aksu, A. E.: The source and origin of the 1929 Grand Banks turbidity current inferred from sediment budget, Geo.-Mar. Lett., 7, 177-182, 1987.

Piper, D. J. W. and Savoye, B.: Processes of late Quaternary turbidity current flow and deposition on the Var deep-sea fan, northwest Mediterranean Sea, Sedimentology, 40, 557-582, 1993.

Piper, D. J. W., Shor, A. N., and Hughes Clarke, J. E.: The 1929 Grand Banks earthquake, slump and turbidity current, Geological Society of America, Special Paper 229, 77-92, 1988.

Piper, D. J. W., Cochonat, P., and Morrison, M. L.: The sequence of events around the epicenter of the 1929 Grand Banks earthquake: initiation of débris flows and turbidity current inferred from sidescan sonar, Sedimentology, 46, 79-97, 1999.

Reading, H. G. and Richards, M.: Turbidite systems in deep-water basin margins classified by grain size and feeder system, AAPG Bull., 78, 792-822, 1994.

Richter, T. O., Van der Gaast, S. Koster, B. Vaars, A. Gieles, R., De Stigter, H., De Haas, H., and van Weering, T. C. E.: The Avaatech XRF core scanner: technical description and applications to NE Atlantic sediments, in: New Techniques in Sediment Core Analysis, edited by: Rothwell, R. G., Geological Society, London, Special Publication, 267, 39-50, 2006.

Roger, J., Hébert, H., Ruegg, J.-C., and Briole, P.: The El Asnam 1980 October 10 inland earthquake: a new hypothesis of tsunami generation, Geophys. J. Int., 185, 1135-1146, 2011.

Rothwell, R. G., Hoogakker, B., Thomson, J., Croudace, I. W., and Frenz, M.: Turbidite emplacement on the southern Balearic Abyssal Plain (western Mediterranean Sea) during Marine Isotope Stages 1-3: an application of ITRAX XRF scanning of sediment cores to lithostratigraphic analysis, in: New Techniques in Sediment Core Analysis, edited by: Rothwell, R. G., Geological Society, London, Special Publication, 267, 79-98, 2006.

Ryan, W. B. F. and Heezen, B. C.: Ionian Sea submarine canyons and the 1908 Messina turbidity current, Geol. Soc. Am. Bull., 76, 915-932, 1965.

Sahal, A., Roger, J., Allgeyer, S., Lemaire, B., H'ebert, H., Schindelé, F., and Lavigne, F.: The tsunami triggered by the 21 May 2003 Boumerdès-Zemmouri (Algeria) earthquake: field investigations on the French Mediterranean coast and tsunami modelling, Nat. Hazards Earth Syst. Sci., 9, 1823-1834, doi:10.5194/nhess-9-1823-2009, 2009.
Semmane, F., Campillo, M., and Cotton, F.: Fault location and source process of the Boumerdes, Algeria, earthquake inferred from geodetic and strong motion data, Geophys. Res. Lett., 32, L01305, doi:10.1029/2004GL021268, 2005.

Serpelloni, E., Vannucci, G., Pondrelli, S., Argnani, A., Casula, G., Anzidei, M., Baldi, P., and Gasperini, P.: Kinematics of the Western Africa-Eurasia plate boundary from focal mechanisms and GPS data, Geophys. J. Int., 169, 1180-1200, 2007.

Silva Jacinto, R., Jamet, G., Babonneau, N., and Cattaneo, A.: Modelling deposition patterns of turbidity events in the Alger Canyon and adjacent Algerian margin: tracking the 2003 Boumerdès event, 18th International Sedimentological Congress, 26 September-1 October 2010, Mendoza, Argentina, 2010.

Stich, D., Serpelloni, E., Mancilla, F., and Morales, J.: Kinematics of the Iberia-Maghreb plate contact from seismic moment tensors and GPS observations, Tectonophysics, 426, 295-317, 2006.

Strzerzynski, P., Déverchère, J., Cattaneo, A., Domzig, A., Yelles, K., Mercier de Lépinay, B., Babonneau, N., and Boudiaf, A.: Tectonic inheritance and Pliocene-Pleistocene inversion of the Algerian margin around Algiers: Insights from multibeam and seismic reflection data, Tectonics, 29, TC2008, doi:10.1029/2009TC002547, 2010.

Stuiver, M., Reimer, P. J., and Reimer, R. W.: CALIB 6.0, available online at: http://calib.qub.ac.uk/calib, 2010.

Van Oudheusden, A.: Les séismes et leurs conséquences sur les câbles, Bulletin de l'Association des Amis des Câbles SousMarins, 24, 7-10, 2003.

Vigny, C., Socquet, A., Peyrat, S., et al.: The 2010 M(w) 8.8 Maule Megathrust Earthquake of Central Chile, Monitored by GPS, Science, 332, 1417-1421, doi:10.1126/science.1204132, 2011.

Wright, L. D. and Friedrichs, C. T.: Gravity-driven sediment transport on continental shelves: A status report, Continental Shelf Res., 26, 2092-2107, 2006.

Yelles, K., Lammali, K., Mahsas, A., Calais, E., and Briole, P.: Coseismic deformation of the May 21st, 2003, Mw $=6.8$ Boumerdes earthquake, Algeria, from GPS measurements, Geophys. Res. Lett., 31, L13610, doi:10.1029/2004GL019884, 2004.

Yelles, K., Domzig, A., Déverchère, J., Bracène, R., Mercier de Lépinay, B., Strzerzynski, P., Bertrand, G., Boudiaf, A., Winter, T., Kherroubi, A., Le Roy, P., and Djellit, H.: PlioQuaternary reactivation of the Neogene margin off NW Algiers, Algeria: the Khayr-Al-Din bank, Tectonophysics, 475, 98-116, doi:10.1016/j.tecto.2008.11.030, 2009.

Yelles-Chaouche, A., Boudiaf, A., Djellit, H., and Bracène, R.: La tectonique active de la région nord-algérienne, Comptes Rendus Geoscience, 338, 126-139, 2006.

Yelles-Chaouche, A., Roger, J., Déverchère, J., Bracène, R., Domzig, A., Hébert, H., and Kherroubi, A.: The 1856 Tsunami of Djidjelli (Eastern Algeria): Seismotectonics, Modelling and Hazard Implications for the Algerian Coast, Pure Appl. Geophy., 166, 283-300, 2009. 